\title{
PARA ALÉM do EgoÍSMo AMBIENTAL: CONTRIBUICÕES DE UMA ÉTICA PÓS-INDIVIDUALISTA PARA A QUESTÃO ECOLÓGICA
}

\author{
[BEYOND ENVIRONMENTAL SELFISHNESS: CONTRIBUTIONS OF A POST-INDIVIDUALIST ETHICS \\ TO THE ECOLOGICAL ISSUE]
}

\author{
Josenir Lopes Dettoni * \\ Universidade Federal de Rondônia, Brasil
}

RESUMo: A proposta do artigo é discutir eticamente o problema dos desafios ecológicos em um tempo de moral individualista. Uma produção filosófica com essas características justifica-se pela possível contribuição ética frente à iminência de uma crise ambiental global que pode causar danos irreparáveis à natureza, grave acirramento de problemas sociais e prejudicar seriamente a qualidade de vida das gerações futuras. Com esse propósito, a problemática aqui abordada pode ser traduzida por meio dos seguintes questionamentos centrais: Como um cenário moral individualista impacta na questão de nossa responsabilidade ético-ambiental? É possível pensar em uma contribuição filosófica para a superação dos problemas decorrentes desse quadro? Para atingir seus objetivos, o presente trabalho dialoga filosoficamente com a teoria da Ética da Responsabilidade, de Hans Jonas. Após uma apresentação sobre a insuficiência do individualismo para o tema da responsabilidade ecológica, o artigo sustenta, como proposta de contribuição para o enfrentamento dessa grave adversidade, a necessidade de um discurso moral que suprassuma o individualismo, um discurso pósindividualista, e suscita questões éticas de relevância voltadas para o futuro.

Palavras-chave: Individualismo; Pósindividualismo; Ética; Ética Ambiental; Ética do Futuro
ABSTRACT: The purpose of the article is to discuss ethically the problem of ecological challenges in a time of individualistic morality. A philosophical production with these characteristics is justified by the possible ethical contribution in the face of the imminence of a global environmental crisis that can cause irreparable damage to nature, severe aggravation of social problems and seriously impair the quality of life for future generations. For this purpose, the issue addressed here can be translated through the following central questions: How does an individualistic moral scenario impact on the issue of our ethicalenvironmental responsibility? Is it possible to think of a philosophical contribution to overcome the problems arising from this situation? To achieve its objectives, the present work dialogues philosophically with Hans Jonas' theory of Responsibility Ethics. After a presentation on the insufficiency of individualism for the theme of ecological responsibility, the article maintains, as a proposal to contribute to the confrontation of this serious adversity, the need for a moral discourse that surpasses individualism, a postindividualist discourse, and raises questions relevant ethics focused on the future.

KEYWORDS: Individualism; Post-individualism; Ethics; Environmental Ethics; Ethics of the Future 


\section{INTRUDUÇÃO}

conhecimento científico produziu recentemente uma técnica com tamanho
poder de intervenção, que o conjunto da natureza terrestre ficou vulnerável à ação humana. Antes, havia rápida recuperação ambiental, o que não comprometia sua 14 continuidade. Em nossos dias, entretanto, enfrentamos a possibilidade concreta de desequilíbrios ecológicos de grande magnitude, que põem em risco a qualidade da vida humana e a sobrevivência de muitas espécies. Assim, uma vez em que temos um grande poder e o exercemos sobre a natureza, tornamo-nos por ela responsáveis.

Contudo, a configuração ética atual parece encontrar dificuldades para assumir essa responsabilidade. De modo marcante, a filosofia ocidental contemporânea tende a indicar os ideais da autossuficiência, independência, emancipação e autonomia como caminhos de realização do ser humano. Em termos práticos, a individualidade passou a ser considerada como valor supremo; e o indivíduo (o que não se divide), como unidade social e fundamento moral.

Quando tal posição teórica se manifesta culturalmente em sua forma exacerbada, temos um individualismo que rejeita os ideais de solidariedade e cuidado para com os demais. De fato, desde essa perspectiva, algumas questões de cunho individualista já se tornam comuns, quando se trata de discutirmos nossa responsabilidade frente à natureza e ao futuro da humanidade: Por que deveríamos nos preocupar com o futuro, se não faremos parte dele? Por que eu deveria fazer sacrifícios em prol das próximas gerações, se elas ainda não existem e são apenas uma ideia? Por que eu deveria deixar de enriquecer por causa do bem de outras pessoas, plantas e animais?

Ora, podemos assim perceber que a ideologia individualista tende a dificultar a responsabilização de cada um perante os problemas coletivos. Em especial, destaca-se o impacto do individualismo no tema da importante questão ambiental que hoje enfrentamos. É possível constatarmos que a própria ideia de indivíduo nos coloca em uma posição de separação com a natureza. Fica estabelecido, então, o substrato ideológico para uma prática ecoindividualista, que também podemos denominar como egoísmo ambiental. Frente a isso, dado o terrível quadro que se prefigura, fica clara, por um imperativo de responsabilidade, a urgente necessidade ética de se rever tal ideologia, de se empreender uma busca filosófica que supere as limitações do individualismo e contribua para orientar a práxis com relação ao meio-ambiente.

A partir desse marco, a problemática abordada neste artigo pode ser traduzida por meio dos seguintes questionamentos centrais: Como um cenário moral individualista impacta na questão de nossa responsabilidade ético-ambiental? É possível pensar em uma contribuição filosófica para a superação dos problemas decorrentes desse quadro?

Para isso, no presente trabalho, após assentarmos a reflexão sobre a insuficiência do individualismo para o tema da responsabilidade ecológica, apresentaremos, ainda que de forma incipiente, elementos de um pensamento pós-individualista necessários para uma ética contemporânea capaz de contribuir para o enfrentamento do problema ambiental atual. Destacaremos a importância da construção de um novo pensamento ético voltado para o futuro, discutiremos aspectos relativos às dificuldades de sua fundamentação, elencaremos traços relevantes de um constructo teórico pós-individualista, bem como teceremos considerações acerca da pertinência da colaboração de áreas como a religião e a educação em sua possível e necessária difusão cultural.

Buscamos, assim, por meio deste esforço filosófico, não só oferecer uma compreensão enriquecida do problema da questão ecológica atual e sua relação com o individualismo contemporâneo, como também apontar uma alternativa de labor filosófico que, comprometido com o futuro da humanidade, contribua para o enfrentamento da grave adversidade mundial ambiental que já dá claros sinais bater às nossas portas.

\section{INSUFICIÊNCIA DO INDIVIDUALISMO PARA O TEMA DA RESPONSABILIDADE ECOLÓGICA}


Uma vez que não vivemos isolados, necessitando dos demais afetiva e materialmente, a convivência com os outros faz com que seja imprescindível estabelecermos relações que possibilitem a sobrevivência de todos os componentes da sociedade. Assim, nossa interdependência não suporta, em longo prazo, um posicionamento ideológico individualista, crescente em nossos dias, já que sua absolutização implicaria na negação dos direitos e interesses dos demais, fazendo com que a vida social se tornasse, em última instância, impossível. Não é sem motivo, portanto, que: "Numa formulação de grande filosofia, poderíamos dizer que o lema máximo da ética é o bem comum. E se hoje a ética ficou reduzida ao particular, ao privado, isto é um mau sinal" (VALLS, 2004, p. 70).

Mau sinal para uma sociedade que, necessitando de unidade para enfrentar graves problemas, tem tendido cada vez mais a considerar o indivíduo e seus interesses como referências para o julgamento acerca do bem. Tal paradigma, evidentemente, não poderá se sustentar por muito tempo. Pelo exposto, não seria temerário, inclusive, afirmarmos que aspectos sociais e teóricos já parecem apontar para a falência de um modelo social individualista exacerbado.

Contudo, o quadro apresentado, infelizmente, pode ainda se agravar. Com relação ao tema ecológico e suas perspectivas futuras, algumas reflexões no campo da Filosofia Política sinalizam que a democracia, modelo político propício para uma cultura individualista, não é capaz de estar à altura de dar respostas satisfatórias para os interesses das próximas gerações, importante elemento abordado pela Ética da Responsabilidade, de Hans Jonas. Ora,

Ocorre que as consequências de nossas decisões avançam no tempo e delas participam não apenas nossos contemporâneos. As gerações futuras não estão presentes, não votam, não têm poder político, não podem opor-se às nossas decisões. Essa enganosa prodigalidade que vivemos significa falência, penúria e sofrimento para as gerações futuras. A maioria dos governantes de hoje estará morta antes que o planeta sofra os efeitos mais graves das chuvas ácidas, do aumento global da temperatura, do esgotamento da camada de ozônio, da incontrolável desertificação, do desaparecimento de número incontável de espécies e da consequente perda da biodiversidade (SIQUEIRA, 1998, p. 53-54).

Sobre o tema, Jonas (2006) mostra-se preocupado e apresenta uma indagação importante: "Que força deve representar o futuro no presente? Essa é uma questão para a filosofia política" (p. 64). Desse modo, o pensador expõe consequências teóricas de sua Ética da Responsabilidade no campo político, estabelecendo uma forte ponte entre ambos. A análise sobre as alterações que a tecnologia trouxe para a vida contemporânea toca de maneira direta aspectos de nossa ação pública. Segundo ele, "nunca antes a política pública teve de lidar com questões de tal abrangência e que demandassem projeções temporais tão longas. De fato, a natureza modificada do agir humano altera a natureza fundamental da política" (JONAS, 2006, p. 44).

Sabemos hoje da precípua necessidade de estabelecimento de políticas globais face aos graves perigos ambientais. Nossa capacidade de destruição da natureza e alteração do meio-ambiente aumentou tanto que agora precisa ser regulamentada e políticas públicas, implementadas, "pois a fronteira entre 'Estado' (pólis) e 'natureza' foi suprimida: a 'cidade dos homens', outrora um enclave no mundo não-humano, espalha-se sobre a totalidade da natureza terrestre e usurpa o seu lugar" (JONAS, 2006. p. 44).

Fica claro que, dada essa nova natureza e dimensão do agir humano, em Jonas, o foco da reflexão ética está posto especialmente no caráter público e objetivo da responsabilidade; e não em seu aspecto subjetivo. Trata-se, portanto, de uma teoria muito mais endereçada à política pública, que propriamente à conduta privada.

E é justamente no âmbito político que Jonas identifica uma grande dificuldade para a adoção de uma prática ética responsável voltada para o futuro:

Decerto que a incerteza das projeções sobre o futuro, inofensiva para a doutrina dos princípios, torna-se uma fraqueza sensível ali onde elas têm de assumir o papel de prognósticos, nomeadamente no emprego prático-político (que, de modo geral, [...] é a parte 
mais fraca de todo o sistema, não só em ternos teóricos, mas também operativos). Pois sabemos que ali o efeito final imaginado deve conduzir à decisão sobre o que fazer agora e ao que renunciar, exigindo-se assim uma considerável certeza da previsão, que justifique a renúncia a um desejável efeito próximo em favor de um efeito distante, que de qualquer modo não nos atingirá (JONAS, 2006. p. 74-75).

Tal carência de poder persuasivo das previsões negativas sobre um futuro não imediato constitui importante debilidade para que a teoria se transforme, de fato, em política, já que, especialmente no modelo democrático, obter anuência de uma maioria em favor de uma renúncia sustentada em cálculos preditivos é, na prática, quase impossível. "[...] Com isso, todas as eventuais intuições obtidas pela casuística não serão aplicadas no devido tempo, em função da natureza inconclusiva dos seus prognósticos, fazendo com que os mais belos princípios permaneçam ociosos, até que seja talvez tarde demais" (JONAS, 2006, p. 75).

Em vista disso, começa a se delinear um pesaroso panorama de impotência da teoria ética comprometida com as futuras gerações de influenciar decisivamente as decisões político-democráticas presentes:

\begin{abstract}
Vale a pena mencionar um outro aspecto da nova ética de responsabilidade pelo, e necessária para $\mathrm{o}$, futuro distante: a insuficiência do governo representativo para fazer face a novos desafios com base nos princípios e nos mecanismos que são normalmente os seus. Pois, de acordo com estes, só os interesses presentes se fazem ouvir e sentir e forçam a que se lhes preste atenção. É perante eles que as iniciativas públicas são responsáveis e é por esta via que se concretiza na prática o respeito de direitos (o que se distingue do seu reconhecimento abstracto). Porém, o futuro não se encontra representado, não é força que faça sentir o seu peso nas escalas de valores. Aquilo que não existe não tem lobby e aqueles que ainda não nasceram são desprovidos de poder. Portanto, a responsabilidade perante eles ainda não tem por detrás dela realidade política na presente tomada de decisões e quando eles puderem fazer valer as suas razões, então nós, os arguidos, já cá não estaremos (JONAS, 1994, p. 57).
\end{abstract}

Ora, torna-se patente a insuficiência da política representativa atual face ao desafio que o problema ambiental constitui, uma vez que, por sua própria estrutura, não é capaz de salvaguardar os interesses das gerações futuras. Assim, ao considerar como diversos modelos políticos poderiam lidar com tais interesses, Jonas (2006) julga que, “[...] diante de uma política futura de sacrifícios responsáveis, a democracia seria, pelo menos momentaneamente, inapta (pois nela predominariam os interesses do presente). Nossa avaliação oscila, a contragosto, entre diferentes tipos de "tirania"' (p. 249).

Nesse sentido, em um contexto individualista, a democracia atual não seria capaz de responder às necessidades da humanidade póstera. Far-se-ia necessária uma forma de governo centralizada e esclarecida para tal. Essa característica, aliás, deveria se estender de maneira global, já que os problemas ambientais, tanto em suas origens quanto em suas consequências, referem-se a todo o planeta. "Today, we are connected to people all over the wold in ways our ancestors could not have imagined. The discovery that human activities are changing the climate of our planet has brought with it knowledge of new ways in which we can harm one another"1 (SINGER, 2011, p. 216).

Quando os países viviam separados em virtude das grandes distâncias e da dificuldade de comunicação existentes no passado, era compreensível que os cidadãos entendessem que apenas seus interesses nacionais deveriam ser defendidos e que, na lógica das relações internacionais, a soberania de cada um fosse respeitada. No entanto, com a revolução social oriunda do processo de globalização, essa forma de pensamento tornou-se anacrônica e, em determinadas situações, até prejudicial.

Inclusive, pode-se analisar esse quadro sob o enfoque do individualismo, considerando o nacionalismo exacerbado, ou ultranacionalismo, uma sorte de individualismo nacional, em que apenas os interesses da nação são considerados. No âmbito do estabelecimento de políticas globais sobre o meio-ambiente, tal posicionamento tem se revelado especialmente danoso.

Ora, já está claro, por exemplo, que em termos de poluição e aquecimento global, 
não se pode mais falar apenas em termos de Estados Nacionais. Trata-se de um processo com causas e consequências mundiais. Nesse sentido, segundo Singer, "[...] the twentyfirst century faces the task of developing a suitable form of government for that single world. It is a daunting moral and intelectual challenge, but one we cannot refuse to take up. The future of the world depends on how well we meet it"2 (SINGER, 2004, p. 200201). Fica evidente aqui a importância de uma Filosofia Política também voltada para o futuro, um pensamento que dê suporte para a superação do individualismo nacional.

$\mathrm{O}$ tema da internacionalização de políticas ambientais também comporta a discussão sobre justiça entre as nações, uma vez que

\begin{abstract}
os países em desenvolvimento suportam a maior parte dos prejuízos dependentes da deterioração do meio ambiente. A tarefa, porém, é para todos, pois toda a família humana sofre com o desaparecimento das selvas tropicais, com a perda das espécies da fauna e da flora, com o acúmulo de resíduos tóxicos e atômicos. Finalmente, nos vemos obrigados a reconhecer que somos tripulantes de uma mesma nau e, imperioso se faz, criarmos mecanismos éticos que mantenham nossa embarcação em condições de navegabilidade nesse imenso mar que é o Universo (SIQUEIRA, 1998, p. 54).
\end{abstract}

Assim, a superação do individualismo nacional, parte de um pós-individualismo político, consiste em imprescindível incumbência para a população mundial, caso, de fato, desde uma perspectiva responsável e justa, escolha garantir um bom futuro para as próximas gerações. Enfim, indubitavelmente, "we need international arrangements to deal with climate change, and we need a global ethic on which to base these arrangements" 3 (SINGER, 2011, p. 218).

Com essas considerações, fica manifesto que, referindo-se a um sujeito ou a uma nação, uma cultura individualista constitui um decisivo empecilho para a efetivação de uma ética da responsabilidade. Na medida em que o eu é considerado o objeto máximo do bem de nossas ações, não é possível que se consolide uma responsável consciência ética aberta à natureza e às futuras gerações.

As consequências de tal postura podem ser, como já vimos, catastróficas. Por conseguinte, parece-nos ser razoável a hipótese de que o acirramento do modelo individualista pode chegar, dentro de um moderado espaço de tempo, até seu esgotamento.

Resta claro, assim, que nos cabe, por um imperativo de responsabilidade, a importante tarefa de construirmos uma cultura ética que supere o individualismo, ou, em termos hegelianos, suprassuma-o, sem necessariamente negar os avanços que a noção de indivíduo nos trouxe; uma ética, portanto, pós-individualista.

\title{
2. ÉTICA PARA O FUTURO AMBIENTAL: RUMO A UMA MORAL PÓS- INDIVIDUALISTA?
}

Tendo ficado patente que o individualismo se revela insuficiente para lidar responsavelmente com o tema ambiental, passaremos agora, ainda que de maneira preambular, a refletir sobre elementos filosóficos que poderiam contribuir para a construção de uma relevante ética com características pós-individualistas.

Discutiremos a necessidade de que ela se oriente para o futuro, abordaremos os temas de sua implicação antropológica e da dificuldade de sua fundamentação, apresentaremos aspectos básicos para a formulação de seu constructo teórico e faremos considerações acerca de como a religião e a educação poderiam contribuir para sua difusão sociocultural.

\subsection{Da necessidade de uma nova ética comprometida com o futuro}

O crescimento do poder humano, por meio do avanço tecnológico, a crise de fundamentação ética em nossos dias e uma cultura ocidental com características 
individualistas cada vez mais marcantes configuram um inequívoco cenário que evidencia a necessidade de nova ética que oriente a ação e o pensamento contemporâneos. Destarte,

a capacidade de intervir através dos recursos da ciência e da tecnologia na natureza e na vida, de invadir os espaços mais íntimos e influenciar os destinos individuais e os rumos da sociedade, de formar opiniões e manipular vontades, desacoplados dos verdadeiros interesses humanos e sociais tornou novamente e tragicamente atual a discussão do tema da ética. Parece necessário estabelecer limites e normas que ordenem as recentes capacidades de intervenção do homem na natureza e na vida. Mas isso é possível? Podemos chegar a um acordo a respeito da validade de normas que sejam vinculantes para todos, ou seja, cujo cumprimento possa ser exigido de todos? (GOERGEN, 2001, p. 8-9)

Uma resposta afirmativa a essa pergunta, apesar de necessária e desejável, não se vislumbra tão facilmente. Sabemos que "para solucionar com êxito os problemas globais precisamos criar novos modelos de pensamento, elaborar uma nova moral e uma nova escala de valores e, sem dúvida alguma, novas normas de comportamento [...]. Nos fazem falta novos conceitos sociais, morais, científicos e ecológicos que deveriam determinar as novas condições de vida do homem atual e o do futuro" (COMISIÓN MUNDIAL DEL MEDIO AMBIENTE Y DEL DESARROLLO, 1992). Tamanho desafio pode figurar-se, para muitos, desalentador.

Contudo, há quem defenda que, diante da clara necessidade de uma nova ética e de uma nova cultura, não se pode "[...] desesperar de que outro horizonte se desenhe como bom sendo que nos permita escapar dos extremos, moralismos e ditaduras, para retomar um movimento que faça reconhecer-nos como seres humanos - os que sobreviveremos como espécie enquanto buscarmos um bem comum e maior que o de cada um [...]" (YUNES, 2009, p. 8).

Segundo tal perspectiva, a crescente preocupação com o futuro da humanidade aponta o advento de um novo paradigma ético. Não seria, assim, desarrazoado “[...] arriscar o diagnóstico de que nos encontramos no limiar do surgimento de uma nova consciência. Parece que se tornam visíveis os primeiros sinais de uma nova percepção, uma consciência de que é urgente e também possível fazer algo para curar as feridas da profunda degradação em que a sociedade fecha o segundo milênio" (GOERGEN, 2001, p. 6). Ora, para a solução dos problemas globais contemporâneos e suas graves consequências em um futuro próximo,

[...] seria melhor, além de mais desejável do ponto de vista moral e pragmático, que a sorte da humanidade pudesse ser confiada a uma 'verdadeira consciência' em expansão, à qual corresponderia um idealismo público, capaz de voluntariamente aceitar sacrifícios em prol das gerações futuras dos seus descendentes e também em prol dos contemporâneos sofredores de outros povos, coisa que a sua situação privilegiada ainda não o exige (JONAS, 2006, p. 247).

Embora Jonas não veja com muita esperança tal cenário, pensamos que justamente a construção dessa consciência expandida, claramente superior ao pensamento individualista, é uma das nobres e importantes tarefas de uma filosofia responsável e focada no futuro. Nessa conjuntura, "num balanço superficial do que essa geração está produzindo, talvez se identifiquem alguns benefícios, porém nossos filhos e as gerações vindouras, sem dúvida, herdarão muitos prejuízos" (SIQUEIRA, 1998, p. 53).

A propósito, dentro desse contexto, componente fundamental do "ser ético" hoje está justamente vinculado à capacidade e ao empenho de pensarmos como construir um amanhã melhor. Nessa perspectiva, "o horizonte da responsabilidade reclama imperativos voltados para a dimensão coletiva, e não mais individual, uma vez que agente, ato e efeito não são mais os mesmos da ética da intenção e proximidade" (ZANCANARO, 1998, p. 58). Assim, uma ética da responsabilidade e uma ética com características pósindividualistas caminham juntas e, em determinados aspectos, implicam-se mutuamente.

No entanto, permanece em aberto a resposta sobre como e quando essa nova consciência ética poderá se estabelecer e apresentar consequências socioculturais efetivas. Sustentamos, sobre isso, a razoabilidade da hipótese de que uma provável crise ecológica 
mundial poderá forçar, de certo modo, a sistematização e difusão de uma nova ecoética. Acerca desse prognóstico hipotético, "podemos pensar que a própria história da filosofia moral proporciona importantes indícios para as épocas em que as pressões sobre normas e valores amplamente aceitos tornaram-se tão esmagadoras que a mudança foi necessária. Se os filósofos pouco fazem para resolver as tensões, eles às vezes fornecem os meios para diagnosticá-las ou até mesmo enfrentá-las" (SCHNEEWIND, 2001, p. 596).

Contudo, tais pressões esmagadoras, e aqui destacamos as oriundas da crise ambiental, não garantem que essa nova ética chegue a tempo e com impacto cultural suficiente para evitar uma catástrofe.

Como vimos, a dificuldade que a Ética hoje enfrenta para encontrar seus fundamentos configura, frente à dimensão da necessidade de uma ética para os nossos tempos, um cenário teórico quase dramático. $\mathrm{O}$ destino da humanidade realmente precisa de uma ética para o futuro que contemple a questão ecológica, muito embora sua fundamentação tenha que desafiar grandes obstáculos.

Tal renovação necessitaria ou poderia se beneficiar de uma mudança paradigmática antropológica que compusesse seus fundamentos? A despeito da conhecida disputa sobre o binômio ser-dever, entendemos que sim. Se não em uma perspectiva de rigor sistemático, certamente como contribuição para sua difusão cultural. Nesse sentido, "altere-se a imagem do homem a seu próprio respeito e estaremos criando uma onda que irá repercutindo e reverberando através dos alicerces da sociedade" (MILLER, 1964, p. 23). No entanto, decerto, uma fundamentação mais rigorosa dos traços essenciais dessa teoria moral será uma importante necessidade teórica a ser sanada no futuro. Tal fundamentação, defendemos, pode e deverá se beneficiar de elementos da tradição filosófica clássica.

Com todo o exposto, "[...] tem de se reconhecer que procurar a sabedoria, hoje, requer uma boa dose de insensatez. A própria essência da época que clama por uma teoria ética faz com que ela se pareça, de modo suspeito, com uma missão de loucos. Porém, não nos resta outra alternativa senão tentá-la" (JONAS, 1994, p. 59). Eis a dimensão de nosso desafio.

\subsection{Uma antropologia para-além-do-indivíduo}

Buscar suporte de uma perspectiva ética na antropologia é um procedimento que enfrenta fortes divergências filosóficas. Todavia, não se pode negar que "as tentativas de manter a estabilidade social e ecológica segundo velhas concepções de proteção ambiental resultaram apenas em mais instabilidade. A criação de um programa que contenha medidas de preservação do ambiente por caminhos seguros passa por um entendimento novo de humanidade" (SIQUEIRA, 1998, p. 57).

Esse novo entendimento antropológico, bem como suas repercussões teóricoculturais, implica em um maior esforço reflexivo do homem rumo ao autoconhecimento. Em outros termos, um momento histórico de grandes transformações, como o que atravessamos, exige também maior compreensão do homem sobre si. Renova-se, portanto, uma vez mais, a necessidade do já antigo preceito "conhece a ti mesmo"!

Nesse caminho, Jonas desenvolve a tese de uma unidade psicofísica da vida como elemento teórico de aproximação entre homem e natureza, fortalecendo a noção de que o homem é parte do meio ambiente, conectado a ele. Tal posicionamento, destacamos, vai de encontro ao substrato antropológico do individualismo, entendendo o homem em sua vinculação com a natureza e os demais, e não apenas como um indivíduo independente.

$\mathrm{O}$ avanço científico contemporâneo parece fornecer elementos que corroboram essa visão. A microbiologia, por exemplo, tem revelado, cada vez mais, nossa interdependência. Basta atentarmo-nos para como aquilo que consideramos nosso corpo tem, de fato, grande parte de sua constituição composta por micro-organismos essenciais para nossa vida. Com efeito, sabemos hoje que há numericamente muito mais microorganismos em nosso corpo do que propriamente células humanas. Nesse sentido, biologicamente, seríamos menos indivíduos e mais ecossistemas. Ou, ainda, mais uma 
comunidade simbiótica do que propriamente um ser individual. Frente a isso, podemos estar diante de uma grande transformação antropológica que possibilite que o "eu", a "identidade", se amplie do indivíduo para algo maior (a comunidade, a humanidade, a biosfera, o universo...).

Ora, quando entendemos que "homem e natureza passam a interdepender-se, a vida 20 de um significa a vida do outro" (SIQUEIRA, 1998, p. 52). Por conseguinte, "a luta contra a morte da natureza e a luta de preservação da humanidade constituem a mesma luta" (SIQUEIRA, 1998, p. 58). Nesse sentido, podemos compreender que, partindo de uma concepção de unidade homem-natureza, "[...] na alternativa 'preservação ou destruição' [...] os interesses humanos coincidem com o resto da vida, que é sua pátria terrestre no sentido mais sublime da expressão [...]" (JONAS, 2006, p. 229).

Eis um crucial elemento do aspecto ecológico da Ética da Responsabilidade de Jonas. Ele "[...] constrói a ideia de uma comunidade única para o destino do homem e da natureza, comunidade que só recentemente se descobriu em perigo e que nos faz reconhecer a dignidade própria da natureza e nos convoca a preservá-la, com um senso muito além do puramente utilitário" (SIQUEIRA, 1998, p. 44).

Tal noção de comunidade única entre homem e natureza provê fulcro para o questionamento acerca de até que ponto seria justificável eticamente a coisificação dos animais pelo homem. Também fornece base para a reflexão sobre seus possíveis direitos. Isto é, "[...] se o dever em relação ao homem se apresenta como prioritário, ele deve incluir o dever em relação à natureza, como condição da sua própria continuidade e como um dos elementos da sua própria integridade existencial" (JONAS, 2006, p. 230).

Outro elemento filosoficamente relevante decorrente dessa concepção antropológica é a defesa de que, dada a unidade homem-natureza, um posicionamento ecoético antropocêntrico seria, de fato, desumanizante. Segundo essa linha argumentativa, "reduzir o dever unicamente do homem para com o homem, desvinculando-o do restante da natureza representaria uma descabida diminuição, mais ainda, seria a desumanização do próprio homem" (SIQUEIRA, 1998, p. 44). Assevera-se, assim, que o reducionismo antropocêntrico desumaniza o homem na media em que o desvincula da Natureza, que o gerou.

$\mathrm{O}$ reducionismo antropocêntrico, que nos destaca e nos diferencia de toda a natureza restante, significa apenas reduzir e desumanizar o homem, pois a atrofia na sua essência, na hipótese mais otimista da sua manutenção biológica, contradiz o seu objetivo expresso, a sua preservação sancionada pela dignidade do seu Ser. Em uma perspectiva verdadeiramente humana, a natureza conserva a sua dignidade, que se contrapõe ao arbítrio do nosso poder. Na medida em que ela nos gerou, devemos fidelidade à totalidade de sua criação. A fidelidade ao nosso Ser é apenas o ápice. Entendido corretamente, esse ápice abrange todo o restante (JONAS, 2006, p. 229).

Esse pensamento revela claramente sua conexão com uma filosofia metafísica. Ora, ainda que uma fundamentação metafísica de uma teoria moral para o futuro possa sofrer fortes críticas, como veremos melhor mais adiante, tal abordagem parece ser um caminho possível de ressignificação moral em uma cultura que se segue a um período de centralidade do eu. Jonas parece coincidir com tal visão. Em suas palavras,

Da orientação interior de sua evolução total talvez seja possível estabelecer uma determinação do ser humano segundo a qual, no ato da auto-realização, a pessoa haveria de realizar um interesse da substância original. A partir daí resultaria um princípio da ética que em última análise não teria seu fundamento nem na autonomia do eu nem nas necessidades da sociedade, mas sim em uma atribuição objetiva por parte da natureza do todo (JONAS, 2004, p. 272).

Consideramos, assim, que, num provável contexto pós-individual, uma ética viável partiria de considerações sobre o "eu" rumo a uma abertura a alteridade, alteridade que também incluiria a natureza. 


\subsection{Sobre o valor e a (im)possibilidade de uma fundamentação metafísica}

Vimos até o presente momento a necessidade de nova ética que seja capaz de, frente aos avanços tecnológicos e aos desafios da crise ecológica, superar uma cultura individualista cada vez mais crescente. Jonas contribui decisivamente com essa reflexão, destacando nossa responsabilidade para com as gerações futuras e o valor da natureza. Para isso, lança mão de uma fundamentação de cunho metafísico. Seu raciocínio é incisivo e questionador: "E se o novo modo do agir humano significasse que devêssemos levar em consideração mais do que somente o interesse 'do homem', pois nossa obrigação se estenderia para mais além, e que a limitação antropocêntrica de toda ética antiga não seria mais válida?" (JONAS, 2006. p. 41).

Sua indagação não pode hoje ser considerada um absurdo, dado que a natureza extra-humana encontra-se atualmente dominada pelo poder do homem, cabendo a nós, portanto, responsabilidade sobre seu futuro; sendo, inclusive, pertinente o questionamento acerca da existência de um valor e de direitos próprios da natureza. Jonas segue sua própria linha reflexiva, esboçando uma resposta:

Se assim for, isso requereria alterações substanciais nos fundamentos da ética. Isso significaria procurar não só o bem humano, mas também o bem das coisas extra-humanas, isto é, ampliar o reconhecimento de 'fins em si' para além da esfera do humano e incluir o cuidado com estes no conceito de bem humano. Nenhuma ética anterior (além da religião) nos preparou para um tal papel de fiel depositário - e a visão científica de natureza, menos ainda. Esta última recusa-nos até mesmo, peremptoriamente, qualquer direito teórico de pensar a natureza como algo que devamos respeitar - uma vez que ela a reduziu à indiferença da necessidade e do acaso, despindo-a de toda dignidade de fins. Entretanto, um apelo mudo pela preservação de sua integridade parece escapar da plenitude ameaçada do mundo vital. Devemos ouvi-lo, reconhecer sua exigência como obrigatória - porque sancionada pela natureza das coisas -, ou então devemos ver nele, pura e simplesmente, um sentimento nosso, com o qual devemos transigir quando quisermos ou na medida em que pudermos nos dar ao luxo de fazê-lo? A primeira alternativa, se tomada a sério em suas implicações teóricas, nos impeliria a estender a reflexão sobre as alterações mencionadas e avançar além da doutrina do agir, ou seja, da ética, até a doutrina do existir, ou seja, da metafísica, na qual afinal toda ética deve estar fundada (JONAS, 2006. p. 41s).

Uma ética assim, claramente justificada na metafísica, e com foco para além do homem, alicerçada na magnitude do ser, pode ser considerada controversa. "Seja como for (e esta é uma ideia reconhecidamente especulativa), só uma ética fundamentada na amplitude do ser, e não apenas na singularidade ou na peculiaridade do ser humano, é que pode ser de importância no universo das coisas" (JONAS, 2004, p. 272).

A discussão sobre a fundamentação de uma teoria ética é de suma importância, já que "justificar um conceito moral significa dar razões para limitar a minha liberdade pessoal e submeter-me a um sistema normativo" (DALL'AGNOL, 2004, p.112). Assim, quando se trata de restringir o domínio de nossas ações, não qualquer critério pode ser evocado como referencial. Quanto a isso, em nossos dias, parâmetros como religião e ontologia encontram-se, no meio filosófico, sob forte suspeição. Contudo, Jonas, ainda que fazendo, sob certos aspectos, restrições ao referencial divino, defende o resgate da fundamentação metafísica:

[...] uma ética que não mais se baseie sobre a autoridade divina tem que fundamentar-se em um princípio que possa ser descoberto na natureza das coisas, para que não seja vítima do subjetivismo ou de outras formas do relativismo. Portanto, enquanto a investigação ontológica extra-humana puder levar-nos para a teoria universal do ser e da vida, ela não se terá afastado realmente da ética, mas terá ido atrás de sua fundamentação possível (JONAS, 2004, p. 252).

Sustentar que é preciso retornar a justificar a ética no plano do "ser", superando paradigmas antiéticos da modernidade, significa a adoção de um posicionamento, deveras, de grande ousadia (ZANCANARO, 1998, p. 69). Jonas, ao longo de sua obra sobre a construção de uma ética responsável que assegure a existência humana futura, permanece 
enfático ao defender que "a justificativa de uma tal ética, que não mais se restringe ao terreno imediatamente intersubjetivo da contemporaneidade, deve estender-se até a metafísica, pois só ela permite que se pergunte por que, afinal, homens devem estar no mundo: portanto, por que o imperativo incondicional destina-se a assegurar-lhes a existência no futuro" (JONAS, 2006, p. 22). Coerentemente a essa convicção de proteção

Jonas mostrará que o excesso de poder da tecnologia se converteu em "ameaça" e "perigo" e que seus conceitos estão indissoluvelmente associados à idéia de "promessa, utopismo, sucesso e bem-estar". Os êxitos e os grandes avanços "afetaram a própria natureza humana" onde os "medos" e os "perigos" levantam a possibilidade de uma catástrofe. Portanto, se temos "poder" e se este foi possível pelo avanço do conhecimento científico, a ética fundada na doutrina do ser abre espaço para dizer "não" ao "não-ser" como se fosse um "sim à vida" (ZANCANARO, 1998, p. 15).

Ora, fica claro que a ideia de que a humanidade deva continuar existindo no futuro é fundamental para uma ética do amanhã e, no entanto, em que pese qualquer crítica contrária, Jonas (2006) argumenta que seu "[...] fundamento último só pode ser metafísico" (p. 47).

Na busca de superação das objeções relativas à impossibilidade de se derivar um dever de um ser, o pensador procura traçar um caminho argumentativo interessante, que apresentamos brevemente a seguir:

A ontologia como fundamento da ética foi o ponto de vista original da filosofia. A separação das duas, que é a separação entre o reino "objetivo" e o "subjetivo", é o destino moderno. Sua re-união, caso seja possível, só poderá ser alcançada a partir do lado "objetivo"; quer dizer: uma revisão da ideia da natureza. E é a natureza no vir-a-ser, mais do que a natureza no permanecer, que oferece tal perspectiva (JONAS, 2004, p. 272).

Todavia, a estratégia de extrair uma ética de uma ontologia, considerada por muitos como falácia, erro categorial ou, até, reducionismo, gera divergências teóricas que estão longe de serem resolvidas no âmbito filosófico acadêmico. Nesse sentido, entendemos que, com a crise da racionalidade atual e o pluralismo cultural de nossa época, a metafísica racional não teria força, ou suficiente eficácia, para fundamentar uma ética que fizesse frente aos problemas futuros, tema que retomaremos mais adiante.

Frente a essa natureza de objeções, uma tentativa de fundamentação alternativa, mais apropriada ao momento filosófico atual, em que impera certo ceticismo moral, seria o recurso da legitimação intersubjetiva:

Para ir além do ceticismo moral não é necessário a volta de uma ética metafísica que defenda critérios universais absolutos fundamentados de uma maneira forte: religiosamente, aprioristicamente ou cientificamente; é plausível pensar que é suficiente que se procure uma forma de legitimar intersubjetivamente alguns princípios morais que sirvam de referência para o julgamento moral (SILVEIRA, 2008, p. 25).

Talvez, no entanto, esse consenso intersubjetivo, tão difícil em tempos de consciência pluralista, só possa ser atingido de maneira global após a força imperiosa de uma catástrofe, como, por exemplo e hipoteticamente, uma de características ambientais.

Contudo, ainda assim, Jonas contra-argumenta que, em última análise, em todo tipo de ética existe uma metafísica implícita. Em suas palavras, "[...] em qualquer outra ética, mesmo naquela mais utilitária, mais eudaimonista e mais imanente, também se esconde implicitamente uma metafísica (o "materialismo", por exemplo, seria uma)" (JONAS, 2006, p. 96).

Ainda assim, é evidente que os obstáculos para o estabelecimento de uma fundamentação aceitável na contemporaneidade não são fáceis de serem superados:

Sem dúvida, é tão difícil criar uma metafísica válida a partir do diktat de uma necessidade amarga quanto criar uma religião; mas a necessidade pode nos obrigar a buscá-la, e o filósofo secular, que se esforça por estabelecer uma ética, deve antes de tudo admitir a possibilidade de uma metafísica racional, apesar de Kant, desde que o elemento racional não 
seja determinado exclusivamente segundo os critérios da ciência positiva" (JONAS, 2006, p. 97).

Vemos, desse modo, que os desafios que precisam ser subrelevados para a formulação de uma ética com tais características ainda configuram grande dificuldade e podem comprometer sua aceitação cultural e, portanto, sua eficácia social. Daí a necessidade de discussão do possível papel auxiliar da religião e da educação neste contexto, o que faremos posteriormente. Antes, porém, cabe-nos agora a apresentação de alguns elementos que poderiam ser aceitos como constitutivos de uma filosofia pósindividualistas.

\subsection{Elementos iniciais de um pensamento pós-individualista}

Como núcleo do presente trabalho, faremos a exposição de nossas considerações sobre uma possível Ética Ambiental voltada para do futuro que seja capaz de superar as limitações do individualismo, aqui também denominada "para-além-do-individualismo". Os elementos a serem apresentados, longe de uma pretensão de sistematicidade, poderiam contribuir para a construção de uma concepção humana e ética mais apropriada para enfrentar importantes desafios vindouros.

Iniciamos abordando os aspectos da interconectividade, interdependência e intersubjetivismo. Sobre isso, entendemos que, ao contrário do que prega o individualismo, "[...] no entrelaçamento indissolúvel dos assuntos humanos, bem como de todas as coisas, não se pode evitar que o meu agir afete o destino de outros; logo, arriscar aquilo que é meu significa sempre arriscar também algo que pertence a outro e sobre o qual, a rigor, não tenho nenhum direito" (JONAS, 2006, p. 84).

Ora, o pensamento pós-individualista pode se constituir como uma ética da interconectividade, da noção de que nos constituímos e sobrevivemos de uma rede de relações. Trata-se da superação da impressão, nesta perspectiva vista como ilusória, de que poderíamos viver de modo independente.

Hoje sabemos que podemos entender o ser humano como local de interdependência e que

Pensar em sujeitos autônomos foi um sonho da modernidade, embalado pela suposição de que a consciência de si e a razão pudessem espantar dependências e atonias sociais. Depois que descobrimos o quanto nossa subjetividade está tocada pelas relações intersubjetivas, uma interdependência histórica e afetiva força os homens a se tomarem como uma humanidade, uma espécie [...] (YUNES, 2009, p. 7).

Assim, em virtude dessa interdependência histórica, podemos entender que não somos apenas indivíduos, somos também parte de um movimento de milhares de gerações. E mais: além de passado, somos igualmente parte constituinte das gerações futuras.

Quanto à intersubjetividade, pensadores como Taylor já têm se manifestado de maneira contundente. Acerca da constituição do self, o autor é taxativo: "Os outros significantes (Habermas deve muito a George Herbert Mead) não são apenas externos a mim; eles ajudam a constituir minha própria identidade. [...] Quando entendemos que os agentes são constituídos pelo intercâmbio, compreendemos que a razão avança também em outra dimensão, a da busca racional de consenso por meio de argumentação" (TAYLOR, 2013, p. 650).

Fica claro que tal posicionamento possui característica pós-individualista. Por

"[...] o self ser constituído pelo intercâmbio na linguagem [...]" (TAYLOR, 2013, p. 650), Taylor (2013) propõe "a busca das fontes morais fora do sujeito por meio de linguagens que ressoem dentro dele [...]" (TAYLOR, 2013, p. 651). Já não se trata, por conseguinte, de erigir o indivíduo como único referencial moral, mas, a partir de uma renovada concepção de si, ir além dele. "Trata-se, portanto, da tentativa de superar o paradigma da filosofia da subjetividade e alcançar o da intersubjetividade" (GOERGEN, 2001, p. 40). 
Em suma, em uma perspectiva pós-individualista, "de fato, só realizamos plenamente a subjetividade de cada um em uma relação necessária de intersubjetividade" (BERTIOLI, 2015, p. 36). Nesse sentido, visar realmente o bem da pessoa é, implicitamente, visar o bem social e viceversa.

Outro elemento importante do pensamento que aqui defendemos, central até, é o da 24 compreensão de que o pós-individualismo não seria uma proposta de suplantar ou derrotar o individualismo, mas de suprassumi-lo. Uma concepção que, ao abarcar as tensões entre as dimensões individuais e coletivas, suprime-as, guarda-as e as eleva a um novo grau, em uma evolução tanto teórica como história.

Assim, a partir de um resgate e, ao mesmo tempo, renovado aprofundamento antropológico e moral, seria possível sustentar, como resposta ao individualismo atual, que

Toda realidade ética tem a dupla fonte do 'pessoal' e do 'social'; tem um horizonte pessoal e social. Isso porque a pessoa tem uma estrutura de interioridade, mas é também uma realidade aberta, ou seja, uma realidade intersubjetiva ou de alteridade, em que o 'eu' constitui-se e é completado dialeticamente com o 'tu' de outra pessoa, enlaçado com ela e com a comunidade, formando o 'nós'. Não se deve, portanto, entender tal divisão com mentalidade dualista e dicotômica (BERTIOLI, 2015, p. 36).

Ora, se já compreendemos que o individualismo exacerbado é um importante empecilho para a adoção de uma ética ambiental responsável, podemos entender também que o modelo individualista aponta para seu esgotamento. Em outros termos, "[...] a prática da vida contemporânea, fruto do desenvolvimento urbano e tecnológico [...] nos tornou ilusoriamente mais autônomos; porém, está a reclamar uma autonomia de outra ordem a ser gerada por uma discussão da ética, à luz de saberes que efetivamente nos tornem mais conscientes da humanidade que portamos [...]" (YUNES, 2009, p. 8).

Tornou-se evidente que um dos grandes desafios éticos contemporâneos é o acirramento do individualismo. Diante disso se nos apresenta um crucial questionamento: Como estabelecer uma teoria ética que supere o reducionismo do individualismo exacerbado e, ao mesmo tempo, não seja totalitária, anti-individualista, negadora dos avanços alcançados 봉is a hipotética tarefa do pensamento pós-individualista.

Talvez seu ponto de partida possa ser, em um movimento dialético, uma compreensão sintética da dualidade eu X tu; suprassunção compreensiva de que o eu se constitui também do tu.

Nessa perspectiva, seria como se o homem atual, de tanto olhar para si, descobrisse que o eu não é simplesmente unitário, mas um ponto de encontro de ampla gama de elementos. A individualidade, aqui, seria considerada como a configuração particular, única, de elementos coletivos. Nesse sentido, somos coletividade; ou, de modo mais apropriado: a individualidade é também coletividade.

Ora, tal abordagem, pós-individualista, não acabaria por "diluir" o sujeito, ou o indivíduo, ou a pessoa? Não, ela ampliaria o campo de visão, enriquecendo nossa perspectiva antropológica e, assim, superando o reducionismo individualista, dando base para um posicionamento ético mais abrangente.

Dessa forma, o pós-individualismo não seria anti-individualismo. Aliás, surgiria do aprofundamento da análise do indivíduo para, a partir dele, e não contra ele, abrir-se a novos horizontes conceituais. Assim, não se trataria simplesmente de negar o indivíduo, mas de descobrir nele o "comunitário" que o constitui e, de certo modo, o ultrapassa.

Por sua natureza sintética, o pós-individualismo não rejeitaria o valor conceitual da individualidade, uma vez que

[...] por si, não há nada que indique que a realização subjetiva não seja um bem. Isso indica apenas que ela precisa fazer parte de um "pacote", ser procurada dentro de uma vida que também almeje outros bens. É claro que isso pode ser a base de um dilema cruel, em que as exigências e realização opõem-se a esses outros bens [...]. Mas um dilema não invalida os bens rivais. Pelo contrário, ele os pressupõe (TAYLOR, 2013, p. 652).

O Pós-Individualismo, portanto, apresentar-se-ia como pensamento fecundo, porque ofereceria caminho de superação do reducionismo que encerra o homem em si 
mesmo, reconhecendo seu valor e sua abertura para aquilo que, embora o constitua, ultrapassa-o.

Tal perspectiva filosófica, se adequadamente desenvolvida e difundida, poderia promover uma importante mudança paradigmática. De um modelo onde predominam a individualidade, a desconexão, a sensação de independência, a dualidade eu-outro e o interesse local; gradualmente haveria uma ascensão para as noções de participação, conexão, interdependência, unidade eu-todo e responsabilidade global.

Responsabilidade essa que, como vimos, tornou-se hoje imperativa, especialmente quando abordamos as questões ambientais. Ora, se considerarmos que vivemos atualmente em um mundo globalizado e que nossas ações ganharam novas dimensões e repercutem na vida de todos os habitantes do planeta, uma mudança paradigmática como a que estamos descrevendo apresenta-se como de extrema necessidade.

Desse modo, vivendo e atuando em uma comunidade global, busca-se, no momento presente, uma indispensável configuração ética dessas mesmas dimensões, com regras morais que possam ser aceitas por todos.

Se o que é determinante para uma moral é o respeito pelo outro, então é possível conceber regras morais que sejam universais, isto é, que se referem a todos e que sejam igualitárias, ou seja, que qualquer pessoa possa aceitar. Possuem validade aquelas normas que, na perspectiva de qualquer integrante de uma comunidade moral, podem ser aceitas pelos diferentes seres capazes de co-operação moral (DALL'AGNOL, 2004, p. 114).

Uma realidade de ações planetárias requer também uma ética planetária. Sem embargo, na busca de superação de éticas locais, deparamo-nos com o fato de que, até o hoje, predominam as moralidades regionais, limitadas, portanto, a seu próprio âmbito. É nesse sentido que podemos entender MacIntyre (2001) ao afirmar que "as filosofias morais, [...] embora possam ter aspirações mais pretensiosas, sempre expressam a moralidade a partir de algum ponto de vista social e cultural [...]” (p. 450).

A exigência agora é por uma ética apropriada ao novo estágio histórico no qual estamos ingressando. Contudo, há que se superar filosóficas objeções analíticas e relativistas sobre o tema. É MacIntyre (2001) quem mais uma vez alça sua voz para afirmar que "o progresso da filosofia analítica teve êxito ao definir, pois, que não há nenhuma base para se acreditar em princípios necessários universais - fora de investigações puramente formais - a não ser relativamente a algum conjunto de hipóteses" (p. 447).

Nesse contexto, entendemos que uma possível, e até provável, crise ambiental global impor-se-á como fato irrefutável a servir de fundamento planetário para esse conjunto de hipóteses. O tema ecológico, assim, por atingir a todos, pode vir a servir como adequado, mas talvez infeliz, ponto de partida para a construção de uma ética de características globais. Não seria inverossímil, destarte, cogitar que estamos no limiar de um novo paradigma civilizatório.

Por outro lado, a globalização, fenômeno recente na história da humanidade, em um primeiro momento, tem nos revelado formas de pensar e valores diferentes dos nossos, favorecendo o pensamento relativista, tanto cultural como filosófico. No entanto, entendemos que, com o tempo, o mesmo processo globalizador tenderá a promover um pensamento universal unificado.

Além de global, é admissível que uma futura ética com essas características seja também ecocêntrica, capaz de valorizar a Terra como um macrossistema orgânico onde tudo é constituído por suas relações. Sobre o tema, Talbot (2012) destaca que

Another way of motivating the ecocentrists' claim is to argue that everything is constituted by its relations to everything else. This suggests that our intuitive desire to see the individual as primary is wrong. The individual is nothing more than a 'nude' in a network of relationships. It is the relationships that are primary. One way of understanding this is to think of a spider's web, where the slightest impact on any part on the web affects every other part of the web ${ }^{4}$ (p. 421-422).

Sob essa perspectiva de interconectividade, ao percebermos que somos um com a 
natureza, nosso posicionamento diante dela tende a se transformar. Uma mudança que parte do antropocentrismo para uma possível perspectiva ecocêntrica pós-individual. Estaríamos diante de uma alteração de rota que nos permitiria entender que "a ameaça à integridade do mundo da natureza nos dirige um forte apelo. Não há nenhuma possibilidade de existência desvinculada e autônoma e, efetivamente, tudo o que existe é dependente" (SIQUEIRA, 1998, p. 58).

Tal movimento pós-individualista poderia criar as condições teóricas e culturais para o surgimento de uma ética que, mesmo sendo humana, deslocasse-se de uma posição antropocêntrica radical e passasse a considerar seriamente o valor das outras vidas existentes. A Ética da Responsabilidade parece já esboçar esforços iniciais nesse sentido, uma vez que "[...] Jonas articula a necessidade de preservar a integridade do mundo e da vida, defendendo um direito moral próprio da natureza. Trata-se de reconhecer um "fim em si”, também na natureza, e não apenas no homem" (ZANCANARO, 1998, p. 57). Mesmo com um posicionamento ainda fundamentalmente centrado no ser humano, o pensador já trabalha na "[...] busca de um imperativo para preservar a natureza, considerando-a como um fim em si mesmo e, acima de tudo, imprescindível para a manutenção da vida humana" (SIQUEIRA, 1998, p. 49).

Podemos perceber, dessa forma, um crescente movimento teórico de valorização e cuidado da natureza. Gradualmente, ela vem sendo considerada como um fim em si. "Em suma, as novas dimensões do agir exigem uma nova ética fundada na perspectiva de valorização da vida [...]" (ZANCANARO, 1998, p. 72). Inclusive, a partir dessa compreensão, hoje já se fortalece a discussão acerca de possíveis direitos de animais nãohumanos. Dall'Agnol (2004), sobre isso, é direto: "Todos os seres sencientes, isto é, que possuem um sistema nervoso central ou que de alguma forma possuem sensibilidade para a dor, são objetos de consideração ética" (p. 82).

Independentemente dos progressos futuros sobre direitos animais, o que já está claro é que as dimensões do novo agir humano exigem uma ética de preservação da natureza que

“[...] ultrapassa a visão antropocêntrica tradicional. [...] Se a natureza extra-humana e a biosfera estão submissas ao nosso poder, torna-se necessário buscar um "bem moral", não somente para a humanidade, mas também para a natureza. Considerando a capacidade destrutiva da tecnologia, a natureza passa a ser incluída na esfera de responsabilidade do nosso agir. Em suma, devemos buscar não só o "bem" do homem, como também "das coisas extra-humanas"”. (ZANCANARO, 1998, p. 56)

Quando superarmos a visão reduzida que o antropocentrismo nos oferece, poderemos passar a aceitar o conceito de unidade homem-natureza e adotarmos valores de preservação do meio-ambiente. Enquanto estivermos centrados em nossos interesses, em especial nos interesses individuais, a natureza tenderá a permanecer sendo utilizada como objeto a nosso dispor. Quanto a isso, uma nova consciência ética nos ensina que "morre a natureza e, em consequência, morre também o homem. O perigo de destruição da natureza, assim como da própria vida humana, impõe-nos o dever de acolher uma ética da conservação, da cautela, da prevenção e não do progresso a qualquer custo, mesmo porque se trata, em última instância, da custódia da própria vida" (SIQUEIRA, 1998, p. 52).

O tema da preservação ambiental guarda também relação com a questão da justiça, justiça social e justiça intergeracional. Em termos sociais, embora saibamos que uma crise ecológica poderá afetar a todos, o que nos convocaria para uma postura solidária e, portanto, contrária ao individualismo exacerbado, nem todos serão afetados da mesma forma. Como expusemos anteriormente, é possível antever prejuízos muito maiores impostos aos mais pobres.

Quanto à justiça intergeracional, consideramos que uma ética capaz de superar o individualismo atual e que estivesse voltada para a situação ambiental do amanhã constituiria grande contribuição para o respeito às gerações futuras. A esse respeito, encontramos no pensamento de Rawls relevante instrumento teórico a iluminar a questão. $\mathrm{O}$ autor propõe a busca da justiça por meio de escolha de princípios em uma situação 
inicial de equidade, também denominada véu da ignorância:

The idea of the original position is to set up a fair procedure so that any principles agreed to will be just. The aim is to use the motion of pure procedural justice as a basis of theory. Somehow we must nullify the effects of specific contingencies which put men at odds and tempt them to exploit social and natural circumstances to their own advantage. Now in order to do this I assume that the parties are situated behind a veil of ignorance. They do not know how the various alternatives will affect their own particular case and they are obliged to evaluate principles solely on the basis of general considerations. [...] They must choose principles the consequences of which they are prepared to live with [... ${ }^{5}$ (RAWLS, 1972, p. 136-137).

Nessa linha, o respeito às gerações futuras fica contemplado nessa forma de procedimento hipotético, uma vez que a contingência temporal, geracional, passaria a ser desconhecida ao se estabelecer os princípios éticos garantidores da justiça. Estaríamos, assim, diante da busca de uma equidade intergeracional.

Tal noção nos mostra que deve haver um equilíbrio e uma busca de igualdade de oportunidades. Todos, inclusive as gerações futuras, devem possuir o direito a uma participação equitativa dos bens da humanidade. Assim, os bens naturais também devem ser conservados para as próximas gerações. Elas também devem ter direito a usufruir de ar puro, água potável e demais riquezas naturais necessárias para uma vida de qualidade. Desse modo, essa concepção estabelece nosso dever para com aqueles que ainda não nasceram, dever certamente negligenciado por uma ética e uma cultura que pregam o bem individual como valor máximo a orientar nossas ações.

Ora, entregarmos às próximas gerações um mundo melhor do que nós recebemos é visto, em uma perspectiva pós-individualista como a que vislumbramos, não apenas como um dever de justiça, mas também como um verdadeiro ato de amor intergeracional capaz de conferir sentido a nossa existência. Nesse sentido, entendemos que "[...] la vera dinamica dell esistenza umana va al di là dell individuo stesso ed rivolta all ‘altro: a qualcosa o a um compito o all amore verso altre persone"6 (PETRINI, 1999. p. 216).

Com efeito, sobre essa verdadeira dinâmica existencial iluminada pelo amor, Jonas (2004) preconiza que

[...] a necessidade para o amor ao próximo, ou a benevolência no uso da teoria, procede do fato de que o poder, por sua própria natureza, é um poder tanto para o mal como para o bem. Mas o amor ao próximo não é ele mesmo um dos frutos da teoria no sentido moderno. Como condição que qualifica seu uso - de que uso se trata, a teoria não especifica, nem muito menos o garante -, ele tem que nascer de uma fonte que ultrapassa o conhecimento garantido pela teoria (p. 216-217).

Essa fonte pode ser encontrada em nossa tradição ocidental e servir como manancial para uma teoria ética iluminada pelo amor na importante busca por uma teoria moral que tenha forças para superar o individualismo exacerbado de nossos tempos. Segundo Valls (2004),

Vivemos numa sociedade pluralista, onde é uma questão de respeito aceitar ou ao menos tolerar hierarquias de valores diferentes das minhas. Mas há uma tradição venerável em nosso Ocidente, que nos ensina que a melhor maneira de nos relacionarmos com os outros é a maneira amorosa. E esta tradição com enorme sabedoria, fornece o critério, o padrão ou a medida deste amor: amar aos outros como amamos a nós mesmos (nem mais e nem menos). Pode ser difícil, mas ninguém discordará que é um ideal ético muito respeitável (p. 72).

Contudo, apesar de sua riqueza, a revalorização de alguns princípios dessa tradição vinculada à religião cristã não é tarefa fácil no âmbito da filosofia contemporânea. As críticas a sua fundamentação são consistentes e nutrem uma forte tendência a sua rejeição. Nem por isso, no entanto, deixa de ser útil, após apontamentos sobre elementos iniciais de um pensamento pós-individualista, a análise de como o a religiosidade poderia contribuir para a difusão de uma ética pós-individualista frente ao cenário teórico e cultural hodierno. Também o papel da educação somar-se-ia a esse desafio. São essas considerações que 
passamos a fazer a seguir.

\subsection{O POSSÍVEL PAPEL DA RELIGIÃO E DA EDUCAÇÃO NA CONSTRUÇ̃̃O DE UMA CULTURA PÓS-INDIVIDUALISTA}

Durante o percurso reflexivo deste artigo, ficou estabelecido que a questão ambiental constitui hoje obstáculo importante para a manutenção da qualidade de vida das próximas gerações. As dificuldades para o adequado enfrentamento desse problema são diversas e profundas. Em um contexto de niilismo ético, relativismo epistemológico e individualismo moral, a filosofia contemporânea parece não estar à altura de dar uma resposta adequada à gravidade da situação ambiental em nosso planeta. E “[...] mesmo que tivéssemos à nossa disposição um conhecimento do bem que pudesse orientar-nos, isto é, uma verdadeira filosofia, esta provavelmente perceberia que seu conselho é impotente frente à auto-alimentada dinâmica da ciência transformada em uso, isto é, da tecnologia" (JONAS, 2004, p. 219).

Não é descabido, portanto, considerarmos uma possível insuficiência do pensamento ético atual para enfrentar o problema de uma presumível catástrofe ecológica e suas desastrosas consequências. Tal impotência é delineada de maneira clara por Jonas (2006):

Aqui me detenho e todos nós nos detemos. Pois exatamente o mesmo movimento que nos pôs de posse daquelas forças cujo uso deve ser agora regulamentado por normas - o movimento do saber moderno na forma das ciências naturais -, em virtude de uma complementaridade forçosa, erodiu os fundamentos sobre os quais se poderiam estabelecer normas e destruiu a própria ideia de norma como tal (p. 65).

Tamanho "vácuo ético", próprio de uma crise teórica de nossos dias, levanta suspeitas sobre o poder do pensamento filosófico contemporâneo de influenciar os rumos sociais a tempo de evitarmos um cenário de flagelo mundial.

Agora trememos na nudez de um niilismo no qual o maior dos poderes se une ao maior dos vazios; a maior das capacidades, ao menor dos saberes sobre para que utilizar tal capacidade. Trata-se de saber se, sem restabelecer a categoria do sagrado, destruída de cabo a rabo pelo Aufklärung [Iluminismo] científico, é possível ter uma ética que possa controlar os poderes extremos que hoje possuímos e que nos vemos obrigados a seguir conquistando e exercendo (JONAS, 2006, p. 65).

Embora Hans Jonas aposte na questionável possibilidade de uma ética fundamentada metafisicamente para tal tarefa, nossa posição é de que, depois de toda crítica feita à metafísica racional, a religião e a educação poderiam assumir também um papel de destaque nesse processo, já que teriam melhores condições de influenciar mudanças culturais nesse sentido. Eis como Jonas se pronuncia sobre o tema:

[...] não podemos nos poupar da ousada incursão na ontologia, mesmo se o terreno que alcançamos for tão inseguro quanto aquele onde a teoria pura tem de se deter, ainda que ele permaneça eternamente suspenso sobre o abismo do incognoscível. Já demos a entender que a fé religiosa possui aqui respostas que a filosofia ainda tem de buscar, com perspectivas incertas de sucesso (JONAS, 2006, p. 96).

Assim, ao afirmar que a religião possui respostas que a ética ainda não consegue dar, o autor abre espaço para um duplo questionamento: o da capacidade filosófica para responder aos desafios atuais e o de qual papel a religião poderia ocupar nesse contexto.

Quanto ao primeiro, já parece ter ficado claro que a filosofia contemporânea enfrenta uma grave crise epistemológica e de fundamentação ética, o que implicaria em certa insuficiência para contribuir efetivamente, por exemplo, para a discussão ambiental. Crise tão profunda que existe hoje quem chegue a afirmar que "nossas 'intuições' são simplesmente opiniões, nossas teorias filosóficas são o mesmo... uma tarefa razoável para o filósofo é levá-las ao equilíbrio. Nossa tarefa comum são quais equilíbrios existentes 
podem resistir ao exame, mas ainda nos cabe apoiar uma ou outra... Uma vez diante de nós a lista de teorias bem-elaboradas, a filosofia é uma questão de opinião..." (LEWIS, 2001, p. 448).

Quanto ao segundo, dada a dificuldade de a filosofia estabelecer metaprincípios éticos sólidos, importa considerar, para fins pragmáticos, a conveniência do papel da religião no processo de superação de um pensamento individualista, que dificulta a adequada abordagem ético-ambiental. Ora, "seria uma grande ajuda para afastar o desastre ecológico se recuperássemos uma percepção do compromisso com nosso ambiente natural. O viés subjetivista que tanto o instrumentalismo como as ideologias de realização pessoal tornam praticamente inevitável fazem com que seja quase impossível defender essa causa aqui" (TAYLOR, 2013, p. 654). Deste modo, frente à urgente situação ambiental em que nos encontramos e considerando essa espécie de fragilidade filosófica atual, entendemos não ser inverossímil a hipótese de que tende a se fazer cada vez mais necessária a atuação de uma instituição capaz de apresentar um embasamento aceitável pela maior parte da população para uma doutrina de controle comportamental. Tal papel, nesse contexto hipotético, poderá vir a ser ocupado pela religião, uma vez que, reconhecidamente, "[...] por mais poderosas que sejam as fontes naturalistas [da moralidade], o potencial de certa perspectiva teísta é incomparavelmente superior" (TAYLOR, 2013, p. 660).

Jonas reconhece o grande potencial da religiosidade, em especial da categoria do sagrado, para o trato do tema do uso indiscriminado dos avanços tecnológicos e, portanto, também da questão ambiental. No entanto, para não ceder a uma fundamentação religiosa da ética, tenta apresentar a categoria do medo como uma tentativa de alternativa:

\begin{abstract}
Trata-se da questão de saber se, sem ressuscitarmos a categoria do sagrado, a categoria mais meticulosamente destruída pelas luzes da ciência, nos é possível ter uma ética capaz de ombrear com os poderes extremos que hoje possuímos, que constantemente desenvolvemos e quase somos compelidos a usar. Considerando que as consequências do uso desses poderes são suficientemente iminentes para ainda nos chegarem a atingir, o medo poderia aqui fazer as vezes do sagrado - tantas vezes o melhor substituto da virtude ou da sabedoria genuínas (JONAS, 1994, p. 59).
\end{abstract}

Contudo, o medo só parece ser suficientemente forte quando se trata de perigo iminente, não diante de ações que terão consequências no futuro. Em suas palavras, "porém, este meio falta-nos quando se trata das mais distantes perspectivas futuras, que são aquelas que para aqui mais contam, especialmente quando os respectivos começos se afiguram eminentemente inocentes na sua insignificância” (JONAS, 1994, p. 59). Nesse caso, "só o temor sagrado com o seu desassombrado veto é independente dos cômputos do medo mundano e do alívio decorrente da incerteza a respeito de consequências demasiado distantes" (JONAS, 1994, p. 59-60). Assim, a própria heurística do medo proposta por Jonas parece revelar-se insuficiente quando se trata de fundamentar uma ética comprometida com as próximas gerações. Uma vez mais, a religiosidade, muito mais próxima da consciência popular que especulações ontológicas, insinua a pertinência de sua colaboração ante o grande desafio ambiental que se nos apresenta.

Apesar de Jonas não atribuir à religiosidade o papel de protagonista nesse processo, destacando a função da ética para tal, em sua própria análise dos fundamentos do imperativo central de sua Ética da Responsabilidade, o autor destaca sua força:

[...] o novo imperativo diz que podemos arriscar a nossa própria vida, mas não a da humanidade; [...] que nós não temos o direito de escolher a não-existência de futuras gerações em função da existência da atual, ou mesmo de as colocar em risco. Não é fácil justificar teoricamente - e talvez, sem religião, seja mesmo impossível - por que não temos esse direito; por que, ao contrário, temos um dever diante daquele que ainda não é nada e que não precisa existir como tal e que, seja como for, na condição de não-existente, não reivindica existência" (JONAS, 2006, p. 48).

Tais considerações são reforçadas, ainda, quando nos deslocamos do elemento da fundamentação de uma necessária fillosofia voltada para o futuro e passamos a considerar 
aspectos político-sociais relativos ao tema. Ao analisarmos como uma perspectiva éticocultural individualista é contrária a uma ética ecologicamente responsável, deparamo-nos com a seguinte, e no meio filosófico talvez desconcertante, afirmação de Jonas (2006): "O capitalismo necessitaria de um novo movimento religioso de massas para poder romper voluntariamente com o hedonismo que lhe foi incutido graças ao estilo de vida afluente 30 (ou seja, antes que a crua necessidade o force a tal)" (p. 246). Em outros termos, a catástrofe, uma vez estabelecida, pode forçar uma posterior mudança de consciência, mas, se o que se quer é encontrar caminhos para evitá-la, a religiosidade, certamente uma renovada, ganha importância de análise nesse cenário.

Aqui recordamos as observações de um relevante filósofo político, Rousseau (2011), quando afirma que:

Os sábios que desejassem se dirigir ao vulgo com a linguagem deles em lugar daquela do vulgo não seriam compreendidos. Ora, há mil espécies de ideias impossíveis de serem traduzidas para a língua do povo. [...] Assim sendo, não podendo o legislador empregar nem a força nem o raciocínio, impõe-se como necessidade que ele recorra a uma autoridade de outra ordem, a qual possa induzir sem violência e persuadir sem convencer (p. 46).

Essa autoridade é a divina e a linguagem, religiosa. Rousseau (2011) descreve como, a fim de que importantes leis e boas, mas difíceis, mudanças políticas possam ser implementadas, a religiosidade tem sua função: "Essa razão sublime que se eleva acima da compreensão dos homens vulgares é aquela cujas decisões o legislador põe na boca dos imortais para induzir mediante a autoridade divina aqueles que a prudência humana não poderia abalar" (p. 46-47). O filósofo político destaca, assim, a necessidade do recurso religioso por meio da evocação da autoridade divina para a indução de boas ações públicas. Revela-se, deste modo, a pertinência da religiosidade como auxílio para a necessária mudança de comportamento do povo.

Eis aí o que constrangeu em todas as épocas os pais das nações a recorrer à intervenção do céu e honrar aos deuses com sua própria sabedoria, a fim de que os povos, submetidos às leis do Estado, como àquelas da natureza, e reconhecendo poder idêntico na formação do homem e na da cidade, obedecessem livremente e suportassem docilmente o jugo da felicidade pública (ROUSSEAU, 2011, p. 46).

Nesse aspecto da relação entre Religião e política, fica claro o papel da religião ajudando a que se suporte o jugo da vida pública. No caso de nosso foco de análise, a questão ambiental, torna-se patente o potencial do discurso religioso diante da necessidade de alteração dos padrões de consumo e poluição que hoje marcam nosso estilo de vida. Contudo, "não é necessário que se conclua de tudo isso [...] que a política e a religião tenham entre nós um objeto comum, mas sim que na origem das nações uma serve de instrumento à outra" (ROUSSEAU, 2011, p. 47).

Diante dessas considerações, mesmo em um contexto de secularização no âmbito teórico e na vida pública, somos convidados a repensar a pertinência de uma possível relação de complementariedade entre religiosidade e filosofia. Para Valls (2004), "em vez de esconder, há que articular a relação entre fé religiosa e saber ético, pois de certo modo a religião, com sua moral, atua no mesmo campo: portanto, ou elas concorrem para fins semelhantes ou elas se excluem polemicamente" (p. 15). Assim, nesse movimento de articulação entre filosofia e fé, entendemos que o filósofo secular pode ser chamado a compreender o papel fundamental que a religiosidade joga no contexto social para fazer frente aos desafios que a humanidade enfrentará no futuro. A esse respeito, Taylor (2013) destaca que "como nossas tradições públicas de família, ecologia e até pólis estão solapadas ou inteiramente desaparecidas, precisamos de novas linguagens de ressonância pessoal para ressuscitar bens humanos cruciais para nós" (p. 654).

Ora, já vimos que uma relação objetal do homem com a natureza a tem levado a um caminho progressivo de destruição. Destruição que não é só dela, mas também nossa. Entendemos que, em termos práticos, o estabelecimento de uma visão de sacralidade da natureza poderia contribuir para uma relação mais sadia com o meio-ambiente. Uma ética, portanto, que se dispusesse a olhar responsavelmente para o futuro ambiental poderia se 
enriquecer ao estabelecer um diálogo com o campo da religiosidade sobre a matéria.

Esse diálogo poderia também auxiliar na resposta ao niilismo de nossos dias. Uma área crucial da pesquisa e do interesse filosófico contemporâneo é o problema da perda de significado em nossa cultura, "de unidade expressiva, de perda da substância e de ressonância em nosso ambiente fabricado pelo homem, de um universo desencantado" (TAYLOR, 2013, p. 650). Universo esse carente de significado dado à impotência filosófica atual de estabelecer fundamentos morais sólidos e a uma cultura fortemente marcada pelo individualismo, que encerra o homem em si, esvaziando-o de um sentido que o transcenda. "[...] Tendemos em nossa cultura a asfixiar o espírito. [...] Excluímos tantos bens de nossa história oficial, enterramos seu poder tão profundamente sob as camadas dos fundamentos racionais filosóficos, que eles estão correndo o perigo de se asfixiar. Ou, melhor dizendo, como são nossos bens, bens humanos, nós estamos nos asfixiando" (TAYLOR, 2013, p. 663).

Entre esses bens humanos, Taylor inclui o conceito de amor, sem o qual nos asfixiamos em uma vida tolhida de grande parte de seu significado. E a fonte de seu resgate pode ser encontrada especialmente no discurso religioso:

A noção cristã original de ágape é de um amor que Deus tem pelos seres humanos, que está ligado a estes serem bons como criaturas (embora não seja preciso definir se são amados por serem bons ou se são bons por serem amados). Os seres humanos participam desse amor por meio da graça. Há uma afirmação divina da criatura, que é captada na frase repetida no capítulo I do Gênesis depois de cada etapa da criação, "e Deus viu que era bom”. A ágape é inseparável desse "ver que é bom" (TAYLOR, 2013, p. 657-658).

Esse "ver que é bom", atribuição axiológica do ser, não se restringe ao ser humano, entendendo-se a tudo o que existe. Independentemente de qualquer insinuação de defesa de alguma religião específica, temos aqui, uma vez mais, o destaque da pertinência da construção de uma responsável teoria ética pós-individualista iluminada pelo conceito de amor como caminho para a valorização da natureza e sua consequente preservação.

Ora, além da já notória defesa sobre a oportuna articulação entre pensamento filosófico e religiosidade como forma de difusão cultural de uma ética pós-individualista comprometida responsavelmente com a natureza e o futuro da humanidade, não podemos deixar de mencionar, já em via de encerramento e ainda que de modo conciso, o papel que a educação pode e deve exercer diante dessa tarefa.

Consideramos, juntamente com Goergen (2001), que "[...] não pode ser ilusão a convicção de que, ante as desgraças e os riscos de outras ainda maiores que estão às nossas portas, é necessário estimular um processo de conscientização que seja capaz de neutralizar estas ameaças. A consciência de que pensar a vida como projeto ainda viável representa pensar a vida no seio da vida, com os outros e com a natureza" (p. 7).

Tal processo de conscientização nasce de um esforço ético sólido, que em nosso caso defendemos ter características pós-individualistas e de comprometimento responsável com o futuro da natureza e da humanidade, mas deve se difundir e consolidar socialmente por meio da educação. Sob essa perspectiva, entendemos que a verdadeira autonomia não é a individualista, mas a que nos possibilita o exercício da responsabilidade. Assim, "é importante considerar que em nossa vida a educação nos abre a possibilidade de superarmos a condição de objetos de responsabilidade para sujeitos dela. Por isso a ética de responsabilidade tem uma dimensão pedagógica que se desloca em todas as direções do nosso agir" (ZANCANARO, 1998, p.10).

Somos responsáveis pelos rumos da importante questão ambiental que enfrentamos e a educação é necessária para estimular essa consciência. "Posto que a tarefa da educação no seu sentido amplo é dar uma formação global de conhecimentos que auxiliam a gestão da vida no mundo, a ética de responsabilidade poderá ser um bom instrumento na valorização da vida, do meio ambiente e de tudo que deve existir" (ZANCANARO, 1998, p. 19).

Por fim, como vimos ao longo de toda a presente argumentação reflexiva, necessitamos superar o individualismo para que, enquanto sociedade, possamos exercer 
nossa responsabilidade ambiental. Estamos frente a uma grave e sem precedentes crise que pode comprometer o futuro da humanidade e de toda a biosfera. A incumbência de construirmos uma suficiente e acertada reflexão ética sobre o tema enfrenta grandes desafios e seu sucesso não é garantido. Além disso, para que sua necessária difusão sociocultural seja efetiva, outros campos do saber devem ser chamados a dar sua colaboração.

Que um responsável esforço ético pós-individualista, uma adequada educação e um renovado conceito do divino possam nos ajudar nessa tarefa!

\section{CONSIDERAÇÕES FINAIS}

Neste trabalho, tratamos de apresentar algumas possíveis contribuições de uma perspectiva ética pós-individualista para a questão ecológica. Partimos do entendimento de que, diante da proximidade de uma crise ambiental, o empenho em pensarmos como construir um amanhã melhor por meio da superação do reducionismo individualista tornase componente fundamental do "ser ético" hoje. Em outros termos, a preocupação com o futuro, com a qualidade de vida das próximas gerações, constitui uma das formas mais relevantes e atuais da reflexão ética. Nesse sentido, uma ética da responsabilidade e uma ética com características pós-individualistas apresentam-se vinculadas, caminham juntas e, em determinados aspectos, implicam-se mutuamente. Aqui, evidenciamos que uma Ética Pós-individualista, como a que se procurou, ainda que de modo incipiente, esboçar neste trabalho, é uma necessidade teórica para que uma Ética da Responsabilidade possa de fato se estabelecer.

Contudo, permanece incerta a resposta sobre como e quando essa consciência ética nova, responsável e pós-individual, poderá se estabelecer e apresentar consequências socioculturais efetivas. A dificuldade que a Ética atualmente enfrenta para encontrar seus fundamentos configura, justamente, diante da grandeza da necessidade presente, um cenário teórico quase dramático. Sobre isso, defendemos a razoabilidade da hipótese de que uma provável crise ecológica mundial poderá forçar a sistematização e difusão de uma nova ecoética. Sem embargo, não há garantias que essa nova ética chegue a tempo e com impacto cultural suficiente para evitar uma catástrofe.

Ora, o destino da humanidade realmente requer uma ética comprometida com o futuro e que contemple a questão ecológica, não obstante sua fundamentação tenha que desafiar grandes empecilhos. Jonas buscou esboçar uma alternativa para isso por meio da antropologia e da metafísica, desenvolvendo a proposição de uma unidade psicofísica da vida como elemento teórico de aproximação entre homem e natureza. Tal posicionamento desafia a base antropológica do individualismo, por entender o homem em sua vinculação com a natureza e os demais, e não simplesmente como um indivíduo independente. $\mathrm{E}$, embora buscar suporte de uma perspectiva ética na antropologia seja um procedimento que enfrenta fortes desavenças fílosóficas, um momento histórico como o que atravessamos exige claramente maior compreensão do homem sobre si, compreensão que o leve ao entendimento de que é parte do meio ambiente, estando a ele conectado. Assim, destacando-se a unidade homem-natureza e indicando seus interesses mútuos, pode-se superar um antropocentrismo reducionista depredatório e desumanizante.

Também a fonte metafísica dessa posição é evidenciada por Jonas ao defender a ideia de que a humanidade deva continuar existindo no futuro, constituindo um dos pontos mais criticáveis de sua teoria. Uma ética justificada na metafísica e com foco para além do homem, alicerçada na magnitude do ser, é considerada controversa. Dada a forte perspectiva positivista-analítica atual, essa característica pode estabelecer grande dificuldade na aceitação de sua obra no mundo acadêmico contemporâneo e, consequentemente, no efetivo impacto social de suas ideias.

Após tais considerações, passamos a apresentar elementos de um constructo teórico pós-individualista, constituintes de uma possível ética ambiental voltada para do futuro, cujos traços colaborariam para a elaboração de uma concepção humana e ética mais 
apropriada ao enfrentamento de importantes desafios vindouros. Com essa tarefa, iniciamos a abordagem dos aspectos da interconectividade, interdependência e intersubjetivismo. Entendemos que um pensamento pós-individualista pode se plasmar uma ética da interconectividade, da noção de que nos constituímos e sobrevivemos de uma rede de relações, superando a impressão, nesta perspectiva vista como ilusória, de que poderíamos viver de modo independente. Por essa ótica, visar o bem da pessoa seria, implicitamente, visar também o bem social e ambiental; e vice-versa. Com isso, estaria também contemplado o reconhecimento do valor de outras vidas, o que possibilitaria lastro para a discussão do direito dos animais não-humanos.

Outro elemento importante do pensamento defendido neste trabalho é o da compreensão de que o pós-individualismo não seria a antítese do individualismo, mas sua síntese. Surgiria do aprofundamento da análise do indivíduo para, a partir dele, e não contra ele, abrir-se a novos horizontes conceituais de superação do reducionismo individualista. Desse modo, não se trataria simplesmente de negar o indivíduo, mas de descobrir nele o "comunitário" que o constitui e, de certa forma, o ultrapassa. Uma concepção que, ao abarcar o conflito entre as dimensões individuais e coletivas, suprimeas, guarda-as e as eleva a um novo grau, suprassumindo-as.

Se adequadamente desenvolvida e difundida, essa visão filosófica poderia colaborar para uma significativa e necessária mudança paradigmática. De um cânone onde prevalecem a individualidade, a desconexão, a sensação de independência, a dualidade euoutro e o interesse local; progressivamente haveria uma evolução para as noções de participação, conexão, interdependência, unidade eu-todo e responsabilidade global.

Vivemos hoje em um ethos cada vez mais globalitário, que demanda uma ética com características correspondentes a essa nova plataforma civilizatória. Embora julguemos que as moralidades regionais devam ser levadas em consideração, entendemos que caminhamos, dados os novos atributos de nossa forma de vida, para a elaboração de uma ética global. Tal movimento pode, inclusive, ser catalisado pelo avanço da crise ambiental planetária.

Além de global, é razoável cogitar que uma futura ética com esses traços tenda a ser ecocêntrica, valorizando a Terra como um macrossistema orgânico em que tudo é constituído por suas relações. Sob essa ótica de interconectividade, ao compreendermos que somos um com a natureza, iniciamos uma transformação que parte do antropocentrismo para uma possível perspectiva ecocêntrica pós-individual. Destarte, ao superarmos a visão reducionista própria do antropocentrismo, poderemos adotar valores mais sólidos de preservação ambiental. Se, por outro lado, mantivermo-nos centrados em nossos interesses, em especial os individuais, a natureza continuará a ser reconhecida e utilizada, com efeitos nefastos, apenas como mero objeto a nosso dispor.

O tópico da preservação ambiental está relacionado também com os temas da justiça social e intergeracional. Em aspecto social, apesar de uma provável crise ecológica atingir a todos, nem todos serão afetados da mesma forma, sendo possível vislumbrar prejuízos muito mais intensos e dolorosos aos mais pobres. Já no que se refere à justiça intergeracional, que comporta a noção de que as gerações futuras devem possuir o direito a uma participação equitativa dos bens da humanidade, defendemos que uma ética capaz de superar o individualismo atual e que esteja voltada para a situação ambiental do amanhã se mostre solidária e comprometida com a conservação dos bens naturais para as próximas gerações. E, ainda, para além de uma questão de justiça, entendemos que o cuidado presente com a natureza, consiste, por seu expresso aspecto de responsabilidade moral e por sua demonstrada necessidade de renúncia à postura individualista, em valoroso ato de amor às próximas gerações, amor intergeracional este capaz de conferir sentido a nossa existência.

Na sequência, após apontamentos sobre elementos iniciais de um pensamento pósindividualista, tecemos considerações sobre a pertinência da possível colaboração de áreas como a religião e a educação na construção de uma cultura com essas características. Ora, sabemos que o labor filosófico pode contribuir para a edificação de uma cultura responsável, comprometida com o futuro e pós-individualista. No entanto, este é um 
processo lento; que, para algumas questões urgentes, pode chegar tarde demais. Examinando o contexto de niilismo ético, relativismo epistemológico e individualismo moral, a filosofia contemporânea enfrenta grandes dificuldades para estar à altura de dar uma resposta adequada à gravidade da situação ambiental em nosso planeta. Logo, não é descabido sopesarmos uma possível e relativa insuficiência do pensamento ético atual para enfrentar o problema de uma presumível catástrofe ecológica e suas desastrosas consequências. Diante dessas considerações, julgamos que a religião e a educação poderiam assumir também um papel de destaque nesse processo, uma vez que teriam melhores condições de influenciar mudanças culturais nesse sentido.

Assim, mesmo em uma conjuntura de secularização no campo teórico e na vida pública, somos convidados a repensar a possibilidade de uma positiva relação de complementariedade entre religiosidade e filosofia. Nesse movimento de articulação entre ambas, entendemos que o filósofo secular pode avançar ao compreender o relevante papel que a religiosidade joga no âmbito social para fazer frente aos desafios que a humanidade enfrentará no futuro. Em termos práticos, pensamos que a instauração de uma visão de sacralidade da natureza poderia auxiliar uma grande massa de população a estabelecer relação mais sadia com o meio-ambiente. Uma ética, por conseguinte, que se dispusesse a lidar responsavelmente com o futuro ambiental poderia se enriquecer ao estabelecer um diálogo com o campo da religiosidade sobre a matéria.

Também nos debruçamos sobre o fundamental papel que a educação pode e deve exercer diante da tarefa de difusão cultural de uma ética pós-individualista comprometida responsavelmente com a natureza e o futuro da humanidade. Consideramos que os rumos da importante questão ambiental que enfrentamos estão em nossas mãos e a educação é estratégica e necessária para estimular essa nova consciência.

Por fim, à guisa de conclusão, destacamos que se a força da tecnologia não pode ser parada, necessita, ao menos, ser guiada para que se tente evitar uma catástrofe. Ao longo desta reflexão, buscamos demonstrar que a questão ambiental constitui hoje importante ameaça para a manutenção das condições que podem garantir qualidade de vida para as próximas gerações. Também evidenciamos como uma ideologia individualista, exacerbadora das noções de autorrealização e independência, plasmada em um egoísmo ético teórico e prático, tende a dificultar a responsabilização de cada um perante problemas coletivos como o ecológico.

Assim, restou comprovada a necessidade de superarmos o individualismo para que, enquanto sociedade, possamos exercer nossa responsabilidade ambiental. No entanto, a tarefa de construirmos uma suficiente e acertada reflexão ética sobre o tema enfrenta grandes desafios e seu sucesso não é garantido. De modo especial, destacamos uma espécie de fragilidade filosófica atual como elemento agravante nesse processo.

Politicamente, ademais, por estarem os governos mundiais comprometidos prioritariamente com o desenvolvimento econômico de seus países, uma solução planetária consensual e unificada para a urgente situação ambiental parece pouco provável. Nesse sentido, defendemos que uma perspectiva pós-individual sobre o ser humano, seus valores e ações poderia ser benéfica tanto para auxiliar os esforços para evitar a catástrofe, quanto para a organização da vida social depois dela, caso ocorra.

Dadas a importância e a urgência do problema e as dimensões dessa catástrofe anunciada, entendemos que todas as opções devem ser adotadas para tentar evitá-la: busca de difusão cultural, por meio da educação, religiões e artes, de uma atitude ética pósindividualista comprometida responsavelmente com a questão ambiental; políticas nacionais e internacionais de redução do impacto humano na natureza; e iniciativas criteriosas de geoengenharia.

Caso isso não seja feito a tempo e com a intensidade necessária, talvez apenas nos reste, infelizmente, como sinal ainda de algum traço de responsabilidade para com as gerações futuras, começar a planejar, seguindo critérios pós-individualistas, o cenário político-sociocultural que seguirá a catástrofe. Ansiamos verdadeiramente que isso não seja necessário.

Com todas essas considerações, esperamos ter oferecido nossa contribuição 
filosófica para a edificação de um pensamento que auxilie a superação das limitações da ideologia individualista, que nos ajude a lidar de modo mais responsável e respeitoso com a natureza e que esteja comprometida com o futuro da humanidade.

\section{REFERÊNCIAS}

BERTIOLI, Antônio Bento. Introdução ao Direito. 14 ed. São Paulo: Saraiva, 2015.

COMISIÓN MUNDIAL DEL MEDIO AMBIENTE Y DEL DESARROLLO. Nuestro futuro común. Madrid: Alianza, 1992.

DALL'AGNOL, Darlei. Bioética: princípios morais e aplicações. Rio de Janeiro: DP\&A, 2004.

GOERGEN, Pedro. Pós-modernidade, ética e educação. Campinas: Autores Associados, 2001.

JONAS, Hans. Ética, medicina e técnica. Lisboa: Vega, 1994.

JONAS, Hans. O princípio responsabilidade: ensaio de uma ética para a civilização tecnológica. Rio de Janeiro: Contraponto: Ed. Puc-Rio, 2006.

JONAS, Hans. O princípio vida: fundamentos para uma biologia filosófica. Petrópolis: Vozes, 2004.

LEWIS, David. Philosophical papers. Volume I. Oxford, 1983. p. x-xi. In: MACINTYRE, Alasdair. Depois da virtude: um estudo em teoria moral. Bauru: EDUSC, 2001.

MACINTYRE, Alasdair. Depois da virtude: um estudo em teoria moral. Bauru: EDUSC, 2001.

MILLER, George A. Psicologia: a ciência da vida mental. Rio de Janeiro: Zahar Editores, 1964.

RAWLS, John. A theory of justice. Oxford University Press, 1972.

PETRINI, Massimo. Geriatria e gerontologia: bioética dell anzianità. In: RUSSO, Giovanni. Bioetica sociale. Torino: Editrice ELLEDICI, 1999.

ROUSSEAU, Jean-Jacques. O contrato social: princípios do direito político. Bauru: EDIPRO, 2011

SCHNEEWIND, J.B. A invenção da autonomia: uma história da filosofia moral moderna. Tradução de Magda França Lopes. Revisão técnica da Álvaro Montenegro Valls. São Leopoldo: Editora Unisinos, 2001.

SILVEIRA, Denis Coitinho. Ensaios sobre ética: complementariedade entre uma ética dos princípios e das virtudes. Pelotas: Editora e Gráfica Universitária, 2008.

SINGER, Peter. One World: the ethics of globalization. New Haven: Yale University Press, 2004.

SINGER, Peter. Practical Ethics. 3 ed. New York: Cambridge University Press, 2011.

SIQUEIRA, José Eduardo de. Ética e Tecnociência: uma abordagem segundo o princípio da responsabilidade de Hans Jonas. Londrina: Editora UEL, 1998.

TALBOT, Marianne. Bioethichs: an introduction. Cambridge: Cambridge University Press, 2012.

TAYLOR, Charles. As fontes do self: a construção da identidade moderna. 4. ed. São Paulo: Edições Loyola, 2013.

VALLS, Alvaro L. M.. Da ética à bioética. Petrópolis: Vozes, 2004.

YUNES, Eliana. Apresentação. In: NEUTZLING, Inácio; BINGEMER, Maria Clara; YUNES, Eliana (orgs.). Futuro da Autonomia: uma sociedade de indivíduos? Rio de Janeiro: Editora Puc-Rio; São Leopoldo: Editora Unisinos, 2009.

ZANCANARO, L. O conceito de responsabilidade em Hans Jonas. 1998. Tese (Doutorado em Educação) Faculdade de Educação, Universidade Estadual de Campinas, Campinas. 1998.

\section{Notas}

1 "Hoje, estamos conectados a pessoas de todo o mundo de maneiras que nossos antepassados não poderiam ter imaginado. A descoberta de que as atividades humanas estão mudando o clima de nosso planeta trouxe consigo o conhecimento de novas maneiras pelas quais podemos prejudicar uns aos outros" (tradução nossa).

2 "[...] o século XXI enfrenta a tarefa de desenvolver uma forma adequada de governo para esse único mundo. É um desafio moral e intelectual assustador, mas que não podemos recusar. O futuro do mundo depende de quão bem encontraremos isso" (tradução nossa).

3 "Precisamos de arranjos internacionais para lidar com as mudanças climáticas e precisamos de uma ética global que sirva de base para esses arranjos" (tradução nossa).

4 "Outra forma de fundamentar a reivindicação dos ecocentristas é argumentar que tudo é constituído por suas relações com todo o resto. Isso sugere que nosso desejo intuitivo de ver o indivíduo como primário está errado. O indivíduo não é nada mais do que um "nó" 
em uma rede de relacionamentos. São as relações que são primárias. Uma maneira de entender isso é pensar em uma teia de aranha, onde o menor impacto em qualquer parte da rede afeta todas as outras partes da rede" (tradução nossa).

5 "A ideia da posição original é estabelecer um procedimento plausível para que quaisquer princípios acordados sejam justos. O objetivo é usar o movimento da pura justiça processual como base da teoria. De alguma forma, devemos anular os efeitos de contingências específicas que colocam os homens em desacordo e os seduzem a explorar as circunstâncias sociais e naturais em proveito próprio. Agora, para fazer isso, eu assumo que as partes estão situadas atrás de um véu de ignorância. Elas não sabem como as várias alternativas afetarão seu próprio caso particular e são obrigadas a avaliar princípios apenas com base em considerações gerais. [...] Elas devem escolher os princípios com cujas consequências estão dispostas a viver [...]" (tradução nossa).

6 "[...] a verdadeira dinâmica da existência humana vai além do próprio indivíduo e se dirige ao outro: a algo ou a uma tarefa ou ao amor por outras pessoas" (tradução nossa). 